\title{
Papers
}

\section{Synergism between allergens and viruses and risk of hospital admission with asthma: case-control study}

\author{
Rosalind M Green, Adnan Custovic, Gwen Sanderson, Jenny Hunter, Sebastian L Johnston, \\ Ashley Woodcock
}

\begin{abstract}
Objective To investigate the importance of sensitisation and exposure to allergens and viral infection in precipitating acute asthma in adults resulting in admission to hospital.

Design Case-control study.

Setting Large district general hospital.

Participants 60 patients aged 17-50 admitted to hospital over a year with acute asthma, matched with two controls: patients with stable asthma recruited from the outpatient department and patients admitted to hospital with non-respiratory conditions (inpatient controls).

Main outcome measures Atopic status (skin testing and total and specific IgE), presence of common respiratory viruses and atypical bacteria (polymerase chain reaction), dust samples from homes, and exposure to allergens (enzyme linked immunosorbent assay (ELISA): Der p 1, Fel d 1, Can f 1, and Bla g 2). Results Viruses were detected in 31 of 177 patients. The difference in the frequency of viruses detected between the groups was significant (admitted with asthma 26\%, stable asthma 18\%, inpatient controls $9 \% ; \mathrm{P}=0.04)$. A significantly higher proportion of patients admitted with asthma $(66 \%)$ were sensitised and exposed to either mite, cat, or dog allergen than patients with stable asthma (37\%) and inpatient controls $(15 \% ; \mathrm{P}<0.001)$. Being sensitised and exposed to allergens was an independent associate of the group admitted to hospital (odds ratio 2.3, 95\% confidence interval 1.0 to $5.4 ; \mathrm{P}=0.05$ ), whereas the combination of sensitisation, high exposure to one or more allergens, and viral detection considerably increased the risk of being admitted with asthma (8.4, 2.1 to $32.8 ; \mathrm{P}=0.002)$.

Conclusions Allergens and viruses may act together to exacerbate asthma.
\end{abstract}

\section{Introduction}

Asthma costs $1 \%-2 \%$ of the total health budgets in direct costs, with equally large indirect costs for time lost from work and reduced productivity. ${ }^{12}$ Much of these costs come from hospital admissions. Being admitted to hospital with asthma is also an important risk factor for death from the condition.
Of 450000 adults admitted yearly with asthma to emergency departments in the United States, an estimated 200000 were sensitised to mite, cat, or cockroach allergen. ${ }^{4}$ Viral respiratory infections have been associated with most acute exacerbations of wheeze in childhood. ${ }^{5}$ In the early part of each school term there is an increase in hospital admissions for asthma associated with the acquisition of new viruses. ${ }^{6}$ An interaction has been suggested between sensitisation and virus infection in exacerbating asthma in children. ${ }^{7}$ Few studies have been conducted in adults, although there is evidence that viral infections are associated with many exacerbations of asthma. ${ }^{8}$ In experimental studies synergistic effects have been shown between allergens and viruses. ${ }^{910}$ No studies have investigated an interaction between sensitisation, exposure to allergens, and viral infections in real life exacerbations of asthma. We therefore determined their relative importance in precipitating acute asthma in adults resulting in admission to hospital.

\section{Methods}

We matched 60 patients (aged 17-50) admitted to hospital over a year with acute asthma for sex, age, and smoking status with two controls: patients with stable asthma recruited from the outpatient department and patients admitted to hospital with non-respiratory conditions (inpatient controls). We enrolled controls within two weeks of the index case being recruited.

We assessed the participants' atopic status by skin prick testing and measurement of total and specific serum IgE levels. We performed nasal lavage for virology, and we made a home visit within three weeks of recruitment to determine exposure to allergens (environmental questionnaire and collection of dust samples).

\section{Assessment of atopic status}

We performed skin prick tests with extracts of nine inhalant allergens (house dust mite (Dermatophagoides pteromyssinus), cat, dog, cockroach, mixed grasses, trees, Trichophyton, Alternaria, Aspergillus, and negative and positive controls; Bayer; Elkahrt, IN). We regarded a weal diameter $3 \mathrm{~mm}$ greater than a negative control as a positive response. We measured total and specific $\operatorname{IgE}$ levels with Pharmacia CAP system.
North West Lung
Centre,
Wythenshawe
Hospital,
Manchester
M23 9LT
Rosalind M Green
research registrar
Adnan Custovic
National Asthma
Campaign senior
clinical research fellow
Ashley Woodcock
professor
Department of
Respiratory
Medicine, National
Heart and Lung
Institute Faculty of
Medicine, Imperial
College of Science,
Technology and
Medicine, London
W2 1PG
Gwen Sanderson
research technician
Sebastian L
Johnston
professor
University
Medicine,
Southampton
General Hospital,
Southampton
SO9 6YD
Jenny Hunter
research technician
Correspondence to:
A Custovic
acustovic@fs 1.
with.man.ac.uk
BMJ 2002;324:1-5 


\section{Detection of viruses}

We collected nasal washings within 24 hours of admission: we inserted a 14 French balloon catheter into the nostrils, inflated the balloon, and instilled $3 \mathrm{ml}$ of sterile saline for 30 seconds before aspiration. ${ }^{8}$ We mixed the lavage fluid with sterile viral culture medium and took an aliquot, which was immediately frozen on dry ice and stored at $-70^{\circ} \mathrm{C}$. We analysed the samples by polymerase chain reaction for picornavirus (rhinovirus, enterovirus), coronavirus 229E and OC43, respiratory syncytial viruses $\mathrm{A}$ and $\mathrm{B}$, influenza viruses $\mathrm{A}$ and $\mathrm{B}$, parainfluenza viruses 1-3, adenoviruses, chlamydia, and Mycoplasma pneumoniae. Our methods were adapted from published ones. ${ }^{11}$ (Details of target genomes, primer sequences, and cycling variables are available on request.) We analysed coded samples blind to groups.

\section{Home visits and exposure to allergen}

We collected dust samples from the participants' mattresses, bedding, bedroom floors, living room floors, upholstered furniture, and kitchens. We extracted the samples and determined the allergens with a two site immunometric enzyme linked immunosorbent assay (ELISA). ${ }^{12-15}$

\section{Statistical analysis}

Our study was designed to identify differences between the groups for the potential risk factors of sensitisation, exposure to allergens, and viral infection. We compared the outcome measures across the groups initially by using appropriate univariate methods $\left(\chi^{2}\right.$ test, one way analysis of variance, and Student's $t$ test). Major exposure occurs with Der p $1 \geqslant 2 \mu \mathrm{g} / \mathrm{g}$, Fel d 1 $\geqslant 8 \mu \mathrm{g} / \mathrm{g}$, and Can f $1 \geqslant 10 \mu \mathrm{g} / \mathrm{g} \cdot{ }^{16}{ }^{17}$ From these values we divided the population into those exposed or not exposed to high levels of allergens. We carried out a further analysis of the risk factors for admission with asthma in the acute and stable asthma groups with logistic regression. Initially we assessed risk factors by univariate analysis. We then tested variables in a multivariate analysis, combining the relevant variables to control for the effect of each explanatory variable on the other variables studied. We explored the synergistic effects by deriving appropriate combinations of factors. We present our results as odds ratios and 95\% confidence intervals.

Table 1 Participants' personal and housing details. Values are numbers (percentages)

\begin{tabular}{lccc} 
& $\begin{array}{c}\text { Patients admitted with } \\
\text { asthma } \mathbf{( n = 6 1 )}\end{array}$ & $\begin{array}{c}\text { Patients with stable } \\
\text { asthma } \mathbf{( n = 5 8 )}\end{array}$ & $\begin{array}{c}\text { Inpatient controls } \\
(\mathbf{n}=\mathbf{5 9})\end{array}$ \\
\hline Median age (years) & 33.1 & 34.3 & 32.9 \\
\hline Male & $18(30)$ & $17(29)$ & $17(29)$ \\
\hline Current smoker & $18(30)$ & $16(28)$ & $16(27)$ \\
\hline Past or never smoker & $43(70)$ & $42(72)$ & $43(73)$ \\
\hline Dog owner & $18(30)$ & $12(21)$ & $16(27)$ \\
\hline Cat owner & $13(21)$ & $17(29)$ & $12(20)$ \\
\hline Other pet owner & $7(11)$ & $7(12)$ & $11(19)$ \\
\hline Double glazing & $20(33)$ & $26(45)$ & $19(32)$ \\
\hline Gas cooker & $36(59)$ & $37(64)$ & $34(58)$ \\
\hline Hard floor in bedroom & $1(2)$ & $1(2)$ & $2(3)$ \\
\hline Central heating & $52(85)$ & $53(91)$ & $55(93)$ \\
\hline Condensation on bedroom window & $31(51)$ & $31(53)$ & $29(49)$ \\
\hline Dampness or mould in bedroom & $4(7)$ & $5(9)$ & $5(8)$ \\
\hline
\end{tabular}

\section{Results}

We recruited 178 patients: 61 admitted with asthma, 58 with stable asthma, and 59 inpatient controls. We matched 57 of the patients admitted with asthma with two controls. One patient admitted with asthma had a control with stable asthma only, two an inpatient control only, and one no suitable controls. Table 1 lists the participants' personal and housing details.

\section{Sensitisation to inhalant allergens}

Significant differences were observed between the three groups in the frequency of positive skin tests for dust mite, cat, dog, and grass allergens but not for other allergens (table 2). No differences were found between patients admitted with asthma and those with stable asthma, and the observed difference between the groups was due to the lower proportion of inpatients being sensitised. Similarly, total and specific IgE levels to mite, cat, and dog allergens were significantly higher in both groups of patients with asthma than in patients admitted with non-respiratory conditions (admitted $v$ inpatient controls: total IgE, mean difference 4.3-fold, $95 \%$ confidence interval 2.4 to $7.6, \mathrm{P}<0.001$; specific IgE to mite, 2.5, 1.2 to $5.0, \mathrm{P}=0.01$; specific $\operatorname{IgE}$ to cat, 4.2, 2.1 to $8.3, \mathrm{P}<0.001$; specific $\mathrm{IgE}$ to $\operatorname{dog}, 2.9,1.6$ to $5.2, \mathrm{P}=0.001$ ) (table 2). Although total serum IgE levels were higher in patients admitted with asthma than in those with stable asthma $(53 \%, 29 \%$ to $96 \%, \mathrm{P}=0.04)$, there were no significant differences between specific IgE levels.

\section{Detection of viruses}

Viruses were detected in 31 of 177 patients (17\%): picornaviruses in 10 and coronavirus in 21. No other viruses or atypical bacteria were detected. A significant difference was found in the frequency of viral detection between the three groups (admitted with asthma $26.2 \%$, stable asthma $17.5 \%$, inpatient controls $8.5 \%$; $\mathrm{P}=0.038)$ (table 2).

\section{Exposure to allergens}

Patients admitted with asthma had significantly higher levels of Der $\mathrm{p} 1$ in their mattress and bedding, Fel $\mathrm{d} 1$ levels in mattress, and Can $\mathrm{f} 1$ in bedroom floor and mattress than patients with stable asthma (table 3). Patients admitted with asthma also had significantly higher levels of Der $\mathrm{p} 1$ in both mattress and bedding than inpatient controls. No differences were observed between patients with stable asthma and inpatient controls. Bla g 2 levels were low and not different between groups (data not shown).

\section{Combinations of sensitisation, exposure to allergens, and viral detection}

Significant differences were observed between the groups for mite, cat, and dog allergens, with the proportion of participants both sensitised and exposed being higher in patients admitted with asthma than either of the control groups (table 4). A significantly higher proportion of patients admitted with asthma $(66 \%)$ were sensitised and exposed to either mite, cat, or dog allergens than patients with stable asthma (37\%) and inpatient controls $(15.1 \% ; \mathrm{P}<0.001)$.

A highly significant difference was observed between the groups for the combination of sensitisation and exposure to high levels of sensitising allergen and viral detection (table 4). 
Risk factors for admission with asthma

We carried out further analysis of the risk factors for admission in patients with acute and stable asthma by using logistic regression. Sensitisation to each or any of the allergens by itself was not significantly associated with hospital admission (table 5). However, being both sensitised and exposed to high levels of dust mite allergen was significantly associated with hospital admission, and strong trends were observed for both sensitisation and exposure to high levels of cat and dog allergens (table 4). Sensitisation and exposure to any one or more allergens was significantly associated with hospital admission (odds ratio 3.2, 95\% confidence interval 1.4 to 7.1). Detection of viruses alone was not significantly associated with admission for asthma (table 5). However, of 16 patients admitted with asthma with detectable viruses, 14 were also sensitised and exposed to high levels of allergen, compared with only 3 of 10 with stable asthma. The combination of sensitisation and high exposure to one or more allergens and detection of viruses was a strong and significant associate of admission for asthma (5.8, 1.6 to 21.6).

When sensitisation, exposure to allergens, and detection of viruses were controlled for, being both sensitised and exposed to allergens was an independent associate of admission with asthma (2.3, 1.0 to 5.4). However, the combination of sensitisation and high exposure to one or more allergens and detection of

Table 2 Sensitisation to allergens, evidence of viral infection, and concentration of total and specific serum IgE to allergens in three groups of patients. Values are numbers (percentages) unless stated otherwise

\begin{tabular}{|c|c|c|c|c|}
\hline & $\begin{array}{l}\text { Patients admitted with asthma } \\
\qquad(\mathrm{n}=61)\end{array}$ & $\begin{array}{l}\text { Patients with stable asthma } \\
(\mathrm{n}=58)\end{array}$ & Inpatient controls $(\mathrm{n}=59)$ & $P$ value \\
\hline Sensitisation to allergens & $n=59$ & $\mathrm{n}=\mathbf{5 8}$ & $\mathrm{n}=59$ & \\
\hline House dust mite & $39(66)$ & $33(57)$ & $22(37)$ & 0.006 \\
\hline Cat & $34(58)$ & $29(50)$ & $9(15)$ & $<0.001$ \\
\hline Dog & $24(41)$ & $22(38)$ & $3(5)$ & $<0.001$ \\
\hline Cockroach & $5(9)$ & $6(10)$ & $8(14)$ & 0.67 \\
\hline Mixed grasses & $35(59)$ & $30(52)$ & $20(34)$ & 0.02 \\
\hline Trees & $8(14)$ & $11(19)$ & $5(9)$ & 0.26 \\
\hline Alternaria & $11(19)$ & $8(14)$ & $2(3)$ & 0.03 \\
\hline Aspergillus & $6(10)$ & $5(9)$ & 2 (3) & 0.33 \\
\hline Trichophyton & $3(5)$ & $5(9)$ & $4(7)$ & 0.34 \\
\hline Positive skin prick test result & $51(86)$ & $43(74)$ & $32(54)$ & $<0.001$ \\
\hline 1 allergen & $8(14)$ & 7 (12) & $14(24)$ & $<0.001$ \\
\hline 2 allergens & $16(27)$ & 8 (14) & $6(10)$ & \\
\hline$\geqslant 3$ allergens & $27(46)$ & $28(49)$ & $12(20)$ & \\
\hline Detection of viruses & $\mathrm{n}=61$ & $\mathrm{n}=\mathbf{5 7}$ & $\mathrm{n}=59$ & \\
\hline Picornavirus & $6(10)$ & $2(4)$ & $2(3)$ & 0.20 \\
\hline Coronavirus & $10(16)$ & 8 (14) & $3(5)$ & 0.18 \\
\hline Any polymerase chain reaction & $16(26)$ & $10(18)$ & $5(9)$ & 0.038 \\
\hline \multicolumn{5}{|c|}{ Total and specific serum IgE level (kAU/l; geometric mean, 95\% Cl) } \\
\hline Total lgE & 253.7 (170.9 to 376.5$)$ & 123.7 (75.7 to 202.2$)$ & 63.2 (38.8 to 103.0$)$ & $<0.001$ \\
\hline House dust mite & $3.3(1.7$ to 6.4$)$ & $2.7(1.4$ to 5.0$)$ & $1.2(0.7$ to 2.2$)$ & 0.02 \\
\hline Cat & $2.5(1.4$ to 4.7$)$ & $1.7(0.9$ to 3.0$)$ & $0.6(0.4$ to 1.0$)$ & $<0.001$ \\
\hline Dog & $1.6(0.9$ to 2.8$)$ & $1.5(0.9$ to 2.5$)$ & $0.6(0.4$ to 0.8$)$ & $<0.001$ \\
\hline Cockroach & 0.5 (0.4 to 0.6 ) & 0.4 (0.3 to 0.5 ) & 0.4 (0.3 to 0.5$)$ & 0.63 \\
\hline
\end{tabular}

Table 3 Concentration of allergens ( $\mu \mathrm{g} / \mathrm{g}$ of dust) to house dust mite, dog, cat, and cockroach from six sites in three groups of patients. Values are geometric means ( $95 \%$ confidence intervals) unless stated otherwise

\begin{tabular}{|c|c|c|c|c|c|c|}
\hline Allergen & Location sampled & $\begin{array}{l}\text { Patients admitted with } \\
\text { asthma }(n=61)\end{array}$ & $\begin{array}{l}\text { Patients with stable asthma } \\
\qquad(\mathrm{n}=58)\end{array}$ & $\begin{array}{l}\text { P value (admissions } \\
\quad v \text { stable patients) }\end{array}$ & Inpatient controls & $\begin{array}{c}\text { P value } \\
\text { (admissions } V \\
\text { inpatients) }\end{array}$ \\
\hline \multirow[t]{6}{*}{ Der $p 1$} & Living room floor & 1.10 (0.67 to 1.82$)$ & 0.73 (0.48 to 1.12$)$ & 0.722 & 0.68 (0.45 to 1.03$)$ & 0.459 \\
\hline & Sofa & 1.75 (0.89 to 2.44$)$ & 1.05 (0.67 to 1.67$)$ & 0.666 & 0.76 (0.53 to 1.11) & 0.102 \\
\hline & Kitchen floor & 0.64 (0.42 to 0.98$)$ & 0.40 (0.27 to 0.57$)$ & 0.238 & 0.39 (0.28 to 0.54$)$ & 0.178 \\
\hline & Bedroom floor & 1.31 (0.85 to 2.02$)$ & 0.73 (0.46 to 1.16$)$ & 0.188 & $0.74(0.47$ to 1.15$)$ & 0.079 \\
\hline & Mattress & 5.02 (2.96 to 8.51$)$ & 1.80 (1.05 to 3.10$)$ & 0.024 & 2.38 (1.49 to 3.81$)$ & 0.05 \\
\hline & Bedding & 5.02 (2.96 to 8.51$)$ & 1.80 (1.05 to 3.10$)$ & 0.024 & 2.38 (1.49 to 3.81$)$ & 0.05 \\
\hline \multirow[t]{6}{*}{ Can $\mathrm{f} 1$} & Living room floor & 7.69 (3.72 to 15.90$)$ & 3.22 (1.54 to 6.75$)$ & 0.130 & 4.63 (2.18 to 9.82$)$ & 0.429 \\
\hline & Sofa & 9.98 (5.10 to 19.53) & 3.31 (1.66 to 6.59$)$ & 0.097 & 6.27 (3.21 to 12.27) & 0.362 \\
\hline & Kitchen floor & 2.57 (1.36 to 4.87$)$ & 1.49 (0.71 to 3.13$)$ & 0.353 & 1.68 (0.87 to 3.23$)$ & 0.438 \\
\hline & Bedroom floor & 3.17 (1.70 to 5.91$)$ & 1.15 (0.58 to 2.28$)$ & 0.05 & 1.57 (0.78 to 3.18$)$ & 0.192 \\
\hline & Mattress & 2.48 (1.27 to 4.82$)$ & $1.07(0.60$ to 1.90$)$ & 0.138 & 1.33 (0.75 to 2.38$)$ & 0.295 \\
\hline & Bedding & 3.32 (1.72 to 6.41$)$ & 1.15 (0.61 to 2.16$)$ & 0.05 & 1.60 (0.82 to 3.13$)$ & 0.210 \\
\hline \multirow[t]{6}{*}{ Fel d 1} & Living room floor & 2.45 (1.17 to 5.14$)$ & 3.98 (1.67 to 9.50$)$ & 0.663 & 3.26 (1.61 to 6.63$)$ & 0.940 \\
\hline & Sofa & 6.68 (2.92 to 15.29) & 7.47 (3.17 to 17.63) & 0.778 & 6.12 (3.13 to 11.97) & 0.458 \\
\hline & Kitchen floor & $1.22(0.51$ to 2.90$)$ & 1.39 (0.62 to 3.12$)$ & 0.729 & 1.13 (0.51 to 2.50$)$ & 0.263 \\
\hline & Bedroom floor & 1.76 (0.79 to 3.91$)$ & 1.04 (0.46 to 2.35$)$ & 0.258 & $1.88(0.90$ to 3.91$)$ & 0.689 \\
\hline & Mattress & 2.39 (1.13 to 5.09$)$ & 0.89 (0.40 to 1.97$)$ & 0.049 & 1.55 (0.74 to 3.22$)$ & 0.181 \\
\hline & Bedding & 2.42 (1.06 to 5.53$)$ & 1.14 (0.50 to 2.61$)$ & 0.098 & $1.90(0.90$ to 4.02$)$ & 0.375 \\
\hline
\end{tabular}


Table 4 Proportion of patients sensitised and exposed to high concentrations of allergen ( $>2 \mu \mathrm{g}$ Der $p 1 / \mathrm{g}$ dust, $>10 \mu \mathrm{g}$ Can $\mathrm{f} 1 / \mathrm{g}$ dust, $>10 \mu \mathrm{g} \mathrm{Fel} \mathrm{d} 1 / \mathrm{g}$ dust) and those with viral infection in three groups of patients. Values are numbers (percentages) of patients unless stated otherwise

\begin{tabular}{|c|c|c|c|c|}
\hline & $\begin{array}{c}\text { Patients admitted with } \\
\text { asthma }\end{array}$ & Patients with stable asthma & Inpatient controls & $P$ value \\
\hline \multicolumn{5}{|l|}{ Sensitisation and exposure } \\
\hline House dust mite & $25 / 55(46)$ & $14 / 54(26)$ & $7 / 53(13)$ & 0.001 \\
\hline Cat & $15 / 55(27)$ & $8 / 56(15)$ & $0 / 54(0)$ & $<0.001$ \\
\hline Dog & $9 / 55(16)$ & $3 / 56(6)$ & $1 / 54(2)$ & 0.013 \\
\hline Any allergens & $36 / 55(66)$ & $20 / 54(37)$ & $8 / 53(15)$ & $<0.001$ \\
\hline 1 allergen & $25 / 55(46)$ & $17 / 54(32)$ & $8 / 53(15)$ & $<0.001$ \\
\hline$\geqslant 2$ allergens & $11 / 55(20)$ & $3 / 54(6)$ & $0 / 53(0)$ & $<0.001$ \\
\hline \multicolumn{5}{|c|}{ Sensitisation and exposure, and detection of viruses } \\
\hline Not sensitised and exposed, no viruses & $17 / 55(31)$ & $27 / 54(50)$ & $42 / 53(79)$ & $<0.001$ \\
\hline Not sensitised and exposed, viruses & $2 / 55(4)$ & $7 / 54(13)$ & $3 / 53(6)$ & $<0.001$ \\
\hline Sensitised and exposed, no viruses & $22 / 55(40)$ & $17 / 54(32)$ & $7 / 53(13)$ & \\
\hline Sensitised and exposed, viruses & $14 / 55(26)$ & $3 / 54(6)$ & $1 / 53(2)$ & \\
\hline
\end{tabular}

viruses increased the risk of admission with asthma $(8.4,2.1$ to 32.8$)$

\section{Discussion}

Admission to hospital with acute asthma in adults was strongly associated with the combination of sensitisation and exposure to high levels of allergens and viral infection. Synergism between these three risk factors is responsible for exacerbation of asthma requiring hospital admission. Few patients were sensitised or exposed to cockroach allergen, in contrast with urban areas of the United States where exposure to cockroach is common and an important risk factor for sensitised patients with asthma attending an emergency department. ${ }^{18}$

\section{Sensitisation and exposure}

Exposure to allergens has been related to disease severity. ${ }^{19-21}$ A significant correlation was found between asthma severity and mite allergen levels in beds in patients sensitised to mites. ${ }^{19}$ Patients with severe asthma were significantly more often sensitised and exposed to high levels of allergens to which they were allergic than patients with mild disease. ${ }^{20}$ Exhaled nitric oxide is higher in patients with asthma who are sensitised and exposed to allergens than in those sensitised but not exposed. ${ }^{21}$ Thus for symptoms to occur

Table 5 Univariate analysis of potential risk factors for admission to hospital in two groups of patients with asthma

\begin{tabular}{|c|c|c|}
\hline & Odds ratio $(95 \% \mathrm{Cl})$ & $P$ value \\
\hline \multicolumn{3}{|l|}{ Sensitisation to allergens } \\
\hline House dust mite & 1.48 (0.70 to 3.12$)$ & 0.31 \\
\hline Cat & 1.36 (0.66 to 2.82$)$ & 0.41 \\
\hline Dog & 1.12 (0.53 to 2.36$)$ & 0.76 \\
\hline Cockroach & 0.80 (0.23 to 2.79$)$ & 0.73 \\
\hline \multicolumn{3}{|c|}{ Sensitisation and exposure to high level of sensitising allergen } \\
\hline House dust mite & 2.38 (1.06 to 5.34$)$ & 0.035 \\
\hline Cat & 2.25 (0.87 to 5.85$)$ & 0.096 \\
\hline Dog & $3.45(0.88$ to 13.53$)$ & 0.075 \\
\hline Any allergens & 3.22 (1.47 to 7.05$)$ & 0.003 \\
\hline 1 allergen & 2.63 (1.14 to 6.06$)$ & 0.023 \\
\hline$\geqslant 2$ allergens & 6.56 (1.63 to 26.46$)$ & 0.008 \\
\hline \multicolumn{3}{|l|}{ Detection of viruses } \\
\hline Any viruses & 1.67 (0.69 to 4.07$)$ & 0.26 \\
\hline Picornavirus & 2.99 (0.58 to 15.47) & 0.19 \\
\hline \multicolumn{3}{|c|}{ Sensitisation and exposure to high level of sensitising allergen, and detection of viruses } \\
\hline Any allergens and any viruses & $5.80(1.56$ to 21.57$)$ & 0.008 \\
\hline
\end{tabular}

there must be both sensitisation and exposure. This was emphasised by the US study in which only children who were both allergic to cockroaches and exposed to high levels of cockroach allergens had significantly higher rates for admission to hospital compared with other children. ${ }^{18}$

\section{Viral infection}

Viral infection was noticeably less common in adults admitted to hospital with acute asthma than in children or adults having asthma exacerbations in the community. ${ }^{5}$ However, viral infection represents a significant risk factor in those patients who are also both sensitised and exposed to allergens. Viral infection in both groups of patients with asthma was more frequent than in inpatient controls. This suggests that patients with asthma are more susceptible to viral infections than patients without asthma but that such an infection may not necessarily induce deterioration in asthma requiring hospital admission. Only 16 of our patients with acute asthma had a positive polymerase chain reaction results for a respiratory virus. This is in contrast to several previous studies in children from our group, which have shown a strong relation between virus infection and exacerbations of asthma. In a community based study, common cold viruses were found in $80-85 \%$ of asthma exacerbations in 9 to 11 year olds. ${ }^{5}$ Twenty two of the our patients who were admitted reported symptoms which they attributed to a cold before admission, but they had negative polymerase chain reaction result for virus. These symptoms may have been due to an allergic response that was mistaken for infection. They could also be true viral infections that were not detected because of one or more of the following factors: sampling late in the course of the illness (for example, the gap between infection and admission could be longer in adults than in children), nasal lavage produced less mucus than an aspirate, or a nasal sample taken instead of sputum sample. However, infection was significantly more common in patients admitted with asthma who were both sensitised and exposed to high levels of allergens than in stable controls who were similarly sensitised and exposed.

\section{Respiratory virus infection and allergic} inflammation

Several experimental studies have shown a synergistic interaction between respiratory virus infection and 


\section{What is already known on this topic}

Studies on segmental allergen challenge of the lung and experimental rhinovirus infection show synergistic effects between allergens and respiratory virus infection

No studies have investigated an interaction between sensitisation, exposure to allergens, and virus infections in real life exacerbations of asthma

\section{What this study adds}

Allergens and viruses may act together to exacerbate asthma, indicating that domestic exposure to allergens acts synergistically with viruses in sensitised patients, increasing the risk of hospital admission

Strategies to reduce the impact of asthma exacerbations in adults should include interventions directed at both viruses and reducing exposure to allergens

allergic inflammation. Fraenkel et al examined the lower airway inflammatory response to viral infection in 17 adults, including six patients with atopic asthma. ${ }^{22}$ Histamine responsiveness and epithelial eosinophils increased during the viral infection but only persisted into the convalescent period in the patients with asthma. Grunberg et al challenged patients with atopic asthma with rhinovirus or placebo. ${ }^{23}$ In the group inoculated with rhinovirus there was no significant change in lung function but there was an increase in bronchial hyper-reactivity and interleukin 8 , which correlated with the severity of the cold. In a study of patients with allergic rhinitis who were sensitised to ragweed, after infection with rhinovirus 16 the patients developed nearly a threefold increased non-specific and specific airway responsiveness during the acute viral infection, with an increased probability of a late asthmatic reaction with ragweed challenge for up to four weeks after the infection. ${ }^{24}$

\section{Conclusions}

Allergens and viruses may act together to exacerbate asthma, indicating that domestic exposure to allergens acts synergistically with viruses in sensitised patients, increasing the risk of hospital admission. In the absence of the effective strategies to control viruses, attention should be paid to reducing exposure to allergens.

We thank Martin Chapman, Martin Brutsche, Helen Marolia, Jill Fletcher, Mandy Mycock, Mark Craven, and Greg Cain for their help, and Julie Morris and Stephen Francis for statistical advice.

Contributors: AC and AW conceived the idea. AW will act as guarantor for the paper. AC, AW, SLJ, and RMG wrote the paper. RMG recruited the participants and collected the data. RMG and AC performed the ELISA analysis of allergen data. GS, JH, and SLJ carried out the polymerase chain reaction analysis of viral data. All were involved in the interpretation of data and final approval of the paper.
Funding: RMG was funded by a scholarship award from the UCB Institute of Allergy, award number 95320. AC is the recipient of the National Asthma Campaign senior clinical research fellowship.

Competing interests: None declared.

1 National Asthma Audit 1999/2000. London: National Asthma Campaign, 1999:12-6.

2 Smith DH, Malone DC, Lawson KA, Okamoto LJ, Battista C, Saunders WB. A national estimate of the economic cost of asthma. Am J Respir Crit Care Med 1997;156:787-93.

3 Campbell MJ, Holgate ST, Johnston SL. Trends in asthma mortality. BMJ 1997;315:1012.

4 Gelber LE, Seltzer LH, Bouzoukis JK, Pollart SM, Chapman MD, Platts-Mills TA.. Sensitization and exposure to indoor allergens as risk factors for asthma among patients presenting to hospital. Am Rev Resp Dis 1993:147:573-8.

5 Johnston SL, Pattemore PK, Sanderson G, Smith S, Lampe F, Josephs L, et al. Community study of role of viral infections in exacerbations of asthma in 9-11 year old children. BMJ 1995;310:1225-9.

6 Johnston SL, Pattemore PK, Sanderson G, Smith S, Campbell MJ, Josephs LK, et al. The relationship between upper respiratory infections and hospital admission for asthma: a time trend analysis. Am J Respir Crit Care Med 1996:154:654-60.

7 Duff AL, Pomeranz ES, Gelber LE, Price GW, Farris H, Hayden FG, et al. Risk factors for acute wheezing in infants and children: viruses, passive smoke and IgE antibodies to inhalant allergens. Paediatrics 1993;92:535-

8 Nicholson KG, Kent J, Ireland DC. Respiratory viruses and exacerbations of asthma in adults. BMJ 1993:307:982-6.

9 Calhoun WJ, Dick EC, Schwartz LB, Busse WW. A common cold virus, rhinovirus 16 , potentiates airway inflammation after segmental antigen bronchoprovocation in allergic subjects. J Clin Invest 1994;94:2200-8.

10 Busse WW, Gern JE. Viruses in asthma. J Allergy Clin Immunol 1997;100:147-50.

11 Chauhan AJ, Johnston SL. Advances in the diagnosis of respiratory infections. In: Skoner, ed, Asthma and respiratory infections. New York: Marcel Dekker, 221-44:2001.

12 Luczynska CM, Arruda LK, Platts-Mills TAE, Miller JD, Lopez M, Chapman MD. A two site monoclonal antibody ELISA for the quantification of the major Dermatophagoides spp. allergens, Der $\mathrm{p} \mathrm{I}$ and Der $\mathrm{f} \mathrm{I}$ J Immunol Methods 1989;118:227-35.

13 Chapman MD, Aalberse RC, Brown MJ, Platts-Mills TAE. Monoclonal antibodies to the major feline allergen Fel d I. II: Single step affinity purification of Fel d I, N terminal sequence analysis and development of sensitive two site immunoassay to assess Fel d I exposure. J Immunol $1988 ; 140: 812-8$

14 Custovic A, Green R, Fletcher A, Smith A, Pickering CAC, Chapman MD, et al. Aerodynamic properties of the major dog allergen, Can $\mathrm{f} 1$ : distribution in homes, concentration and particle size of allergen in the air. Am J Respir Crit Care Med 1997;155:94-8.

15 Pollart SM, Mullins DE, Vailes LD, Sutherland WM, Chapman MD. Identification, quantitation and purification of cockroach allergens using monoclonal antibodies. J Allergy Clin Immunol 1991;87:511-21.

16 Platts Mills TAE, Vervloet D, Thomas WR, Aalberse RC, Chapman MD Indoor allergens and asthma: report of the third international workshop. JAllergy Clin Immunol 1997;100(6):1-21S.

17 Ingram JM, Sporik R, Rose G, Honsinger R, Chapman MD, Platts-Mills TAE. Quantitative assessment of exposure to $\operatorname{dog}(\mathrm{Can} f 1$ ) and cat (Fel d 1) allergens: relation to sensitization and asthma among children living in Los Alamos, New Mexico. J Allergy Clin Immunol 1995;96:449-56.

18 Rosenstreich DL, Eggleston P, Kattan M, Baker D, Slavin RG, Gergen P, et al. The role of cockroach allergy and exposure to cockroach allergen in causing morbidity among inner-city children with asthma. $N$ Engl J Med 1997;336:1356-63

19 Custovic A, Taggart SCO, Francis HC, Chapman MD, Woodcock A Exposure to house dust mite allergens and the clinical activity of asthma. J Allergy Clin Immunol 1996;98:64-72.

20 Tunnicliffe W, Fletcher T, Hammond K, Roberts K, Custovic A, Simpson A, et al. Sensitivity and exposure to indoor allergens in subjects with differing asthma severity. Eur Respir J 1999;13:654-9.

21 Simpson A, Custovic A, Pipis S, Adisesh A, Faragher B, Woodcock A. Exhaled nitric oxide, sensitisation and exposure to allergens in asthmatics not taking inhaled steroids. Am J Respir Crit Care Med 1999;160:45-9.

22 Fraenkel DJ, Bardin PG, Sanderson G, Lampe F, Johnston SL, Holgate ST. Lower airways inflammatory response during rhinovirus colds in normal and asthmatic subjects. Am J Respir Crit Care Med 1995;151:879-86.

23 Grunberg K, Smits HH, Timmers MC, de Klerk EP, de Gouw HW, Kroes $\mathrm{AC}$, et al. Experimental rhinovirus 16 infection. Effects on cell differentials and soluble markers in sputum of asthmatic subjects. Am Respir Crit Care Med 1997;156:609-16.

24 Lemanske RF Jr, Dick EC, Swenson CA, Vrtis RF, Busse WW. Rhinoviru upper respiratory infection increases airway hyperreactivity and late asthmatic reactions. J Clin Invest 1989;83:1-10.

(Accepted 7 November 2001) 